\title{
Negotiating the New Media Platforms: Youth and Political Images in Kenya
}

\author{
Lusike Lynete Mukhongo
}

\author{
Moi University, Nairobi Campus, Kenya, lusikem@mu.ac.ke,www.mu.ac.ke
}

\begin{abstract}
New media platforms, particularly social networks act as vehicles for the visual representation of a nation's political discourse among the youth. Web 2.0 has created online spaces (private and public) that have been appropriated by Kenyan youths, locally, and in the diaspora to weave their own political narratives and present them in forums that accommodate their views without fear of censorship or regulation that characterises "offline" communications. Using post-structuralism, with an emphasis on Roland Barthes's Death of the Author and Camera Lucida, the article critically analyses how cultural values affect the interpretation of online political images from Kenya, by Internet users from different culture zones. Further, the article discusses whether political images posted by the youth in Kenya on their online private spaces can be used to promote political stereotypes, subjectivities and perpetuate visual hegemonies or whether it allows the youth to circumvent government surveillance tactics and affords nations an opportunity to correct the media hegemony by rewriting their own stories on a platform that is not just national, but transnational.
\end{abstract}

Keywords: Connectivity; New Media Platforms; User-Generated Content; Political Images; Algorithms; Surveillance

\section{Introduction}

The Internet has become a primary socio-technical system that shapes and is shaped by modes of living in contemporary capitalism (Fuchs 2012). It is the first truly post-colonial medium in Africa, for the simple reason that its popularity has taken root in a world that is largely decolonized (Douai and Olorunnisola 2013), and its adoption has grown at an exceedingly fast pace in Africa, and Kenya in particular (Martin and Olorunnisola 2013). As a result, there seems to be an undisputed consensus amongst scholars and the wider public that the "rise and normalisation of the internet and overall organisation has brought an enormous change" to the lives of people, particularly the youth (Prodnik 2012, 92). The uses of ICTs (social media, in particular and mobile phones) have been credited with providing platforms on which political, social and economic freedoms can be expanded (Diamond 2010, quoted in Martin and Olorunnisola 2013, 260). Consequently, online social networks are becoming important sources of political information and are offering civic engagement alternatives for young people who usually are not attracted to politics (Auskalniene 2012). However, the attraction of the youth and the political flowering of the Internet is due partly to its current sprawling and relatively unregulated status (Bennett 2004) that attracts the youth to engage in political discussions online. It enables them to post political images that allow them to circumvent government monitoring and surveillance, which ordinarily characterises consumption of information from newspapers, radio and television.

With the proliferation of new media technologies, users have unprecedented capacities to produce and distribute their own information to limited or large audiences within and across national boundaries (Bennett 2004). As a result, social media offers a platform for civic engagement and political activism among the youth in Kenya, and it is obvious that social media as a collective, user-generated platform has numerous possibilities to serve as an alternative space for civic engagement (Auskalniene 2012). By publishing electronically (at no cost, and with a potential to reach a vast audience), the Internet dramatically expands the range of voices heard on many issues (election fraud, disparities in remuneration of public officers, misuse of public resources by state officials), and offers quick access to information 
(Auskalniene 2012; Warf and Grimes 1997). Therefore, a single image can reach a vast audience, which then enables Internet users to draw inferences about the political scene from their varied cultural contexts. Another aspect that makes social networking sites an attractive sphere of political interaction is their potential to provide various opportunities for participation, lower costs of engagement, and build social ties among the citizens (Auskalniene 2012), also referred to as "netizens" (Cammaerts 2009; Bennett 2004; Castells 1997). Social media, therefore, constitutes an integral aspect in Kenya's social and political dynamics. It has been effectively used in driving positive change, galvanising and channelling public discontent, political mobilisation, governance and civil awareness (Omanga and Chepngetich-Omanga 2013) through the use of images posted on Facebook, Twitter, and blogs. It can therefore be pointed out that the advent of Web 2.0 has allowed new media platforms in Kenya, particularly social networks to act as vehicles for the visual representation of a nation's political discourse, participation, protest, and social movements.

\subsection{Rationale}

Effects of new technologies are unique and wide ranging (both in private and public online spaces) and arise from the manner in which the youth appropriate them to substitute for and accomplish previously established communication practices (Bimber, Flanigan and Stohl 2005). The digitalisation of visuals has enhanced the audio-visualisation of the public spheres and varying audio-visual strategies are employed to achieve the attention of culturespecific, trans-cultural and global audiences (Ludes 2005). Often, the youth in Kenya appropriate the visual materials to create their own information environments (characterised by audio-visual formats, often on Facebook, Twitter and YouTube) outside of official governmental and authoritative journalistic sanctioning, governing the large-scale organisation of transnational politics to challenge various aspects of economic globalisation (Bennett 2004), global politics, cultural imperialism, and media hegemonies. This has been made possible because ICTs are technologies of creativity to be used and developed not by technoscience alone but by consumers (Nayar 2010:4). Unlike the parasocial flows that characterised classical forms of political participation, computer-mediated versions of online activity offer more interactive two-way communication flows for participatory actions in society (Auskalniene 2012). The youth in Kenya are embracing social media; twitter has been a key organising medium in popular movements in Kenya (Omanga and Chepngetich-Omanga 2013). In addition, the infrastructure of the Internet and the web 2.0 offers valuable resources to youth and political activists in Kenya to organise for protest movements. For instance, the organisers of Occupy Parliament Movement (OPM) Kenya ${ }^{1}$ that was held on May 14, 2013 relied heavily on social media to mobilise the protesters. ${ }^{2}$

The youth in Kenya have also quickly adopted the internet for political expression because it is a platform that is relatively secure, circumvents monitoring, censorship or regulation by authoritarian regimes, and it is characterised by open source democracy building communication technologies, in challenging the mainstream media regimes (Bennett 2004). The characteristics of Web 2.0 are personalisation and customisation. Furthermore, Web 2.0 allows developments of wikis, blogging, social networking, customised games and personal fabrication (Nayar 2010, 4). Visuals make messages more informative and allow Internet users to convey concise descriptions of the political landscape of a nation. Open source democratisation technologies have been occasioned by the need to open up communication avenues for young people and political activists. With their diverse technologies and Internet applications, they have offered access to a platform free from government controls, particularly in authori-

${ }^{1}$ Occupy Kenya Parliament movement, often abbreviated as OPM Kenya protests, are protests that were held in Kenya on May 14, 2013 and June 11, 2013 by the civil society protesting against attempts by Members of Parliament (MPs) in Kenya to increase their salaries. The civil society used live pigs (a symbol of the greed of the MPS) and poured blood outside the parliament (representing the blood of Kenyans). ${ }^{1}$ Accessed January 14 , 2013. http://www.youtube.com/watch?v=SHrcrFNQEJ8. Running time: (2:37); key audiovisual narratives: 0:25 to $0: 42 ; 02: 00$ to $02: 15$.

${ }^{2}$ Accessed January 14, 2013. http://www.youtube.com/watch?v=SHrcrFNQEJ8. Running time: (2:37); key audiovisual narratives: $0: 25$ to $0: 42 ; 02: 00$ to $02: 15$. 
tarian or emerging democracies. For example, social networking sites (SNS) offer their users multiple interactive ways to upload visuals and use them again in later posts. A user can post a single image on twitter or Facebook, which will draw various and multiple reactions from different segments of the population. These options include posting images on users' walls, using images as responses to comments, images posted in groups, forums, and attachments to private messages (Thackeray 2010). For instance, a simple look at the political images posted on a user's Facebook profile, can reveal a user's political inclinations, based on Web 2.0 being active mediators between users, technologies and content (Dijck 2013).

However, while the internet is a transnational platform, which enables the youth in Kenya to produce, interact with and disseminate political images worldwide, it also serves to promote local counter hegemonic discourses by challenging established systems of domination and legitimating and publicizing political claims by the marginalised groups (Warf and Grimes 1997). During the OPM Kenya protests, users resorted to using the Internet to publicise their political views and sentiments. Images of MPs in the form of pigs (representing greed) were circulated on social media platforms in Kenya. However, while the social media enables the expression of counter hegemonic discourses among young people in Kenya, it also enables a globally networked form of surveillance (Fuchs et al. 2012). The focus of this article is on the appropriation of new media by young people in Kenya. It seeks to show how visual representation of politically relevant scenes may improve political connectivity and sustain counter hegemonic discourses despite government surveillance tactics and yet promote or reinforce cultural relativities, political subjectivities, stereotypes and visual hegemonies. Emphasis is on the use of images to circumvent government surveillance tactics.

The concern of this paper is borne out of the knowledge that while millions of young people in Kenya continue to join the social networks, many of them are unaware that the images they consider to be personal and private, in an era of global communications, become information for public consumption and interpretation. For example, they post images about Kenyans celebrating the election of Uhuru Kenyatta for president who is also an ICC inductee; or they divulge images of political activists using animal blood and live pigs for demonstration in front of the Kenyan parliament without realizing that the information they spread is interpreted differently by people from different cultural zones of the globe. The concern is therefore whether political images posted online can serve to promote political stereotypes, subjectivities and the propagation of visual hegemonies on a global platform or whether they can be appropriated by the youth to express counter hegemonic sentiments and circumvent government surveillance, while at the same time opposing global visual hegemonies.

\subsection{Theoretical Framework}

We can roughly distinguish two kinds of approach in Internet studies that describe themselves as critical. The first has a cultural studies background, the second a political economy background. The theoretical background of the first is roughly post-structuralist; that of the second is Marxist (Fuchs 2012, 394). Poststructuralism challenges the classic understanding of the processes of signification by considering meanings not to be as self-evident as they seem; instead reflects upon the liberating potential of the processes of signification (Stanbridge 2003). Using post-structuralism as its framework, the paper discusses how cultural values affect the choices of images used by young people in Kenya. The paper also examines how online political images from different culture zones, such as the Arab Spring; walk to work protests of Uganda; London protests and England riots in 2011, are being and have been interpreted by young people in Kenya. Post-structuralism will also be used to study how social media has been appropriated by Kenyan youth locally, and in the diaspora as a tool for weaving visual narratives on a national, transnational and global platforms. The first theoretical framework is Roland Barthes's theory of "the death of the author" and his study in photography entitled Camera Lucida. This framework has been chosen in support of two theses concerning the use of political images by young people in Africa: (1) once an image is posted online, the interpretation of the image lies with the readers (online users), and (2) a political image often has multiple meanings, depending on the internet users cultural backgrounds. 
According to Barthes, once a fact is recounted, the voice loses its origin, the author enters his own death, and writing begins (Barthes 1989, 49). Therefore, the meaning of images posted online lies in the various users diverse cultural contexts, and subsequently, how users interpret images online, is then not determined by the intention of the sender, but by the users themselves. The death of the author is necessary for the reader to be liberated and interact meaningfully with an image, in order to derive multiple meanings from it. Further, a text consists not of a line of words, releasing a single meaning but of a multi-dimensional space in which are married and contested several writings, none of which is original, but a fabric of quotations, resulting from a thousand sources of culture (Ibid., 52-53). For instance, during the OPM Kenya protests, several contested denotative and connotative meanings emerged from the protests. We had the use of pigs to symbolise greed of the Members of Parliament by the civil society; the Muslim fraternity felt it was a blasphemy and against the teachings of Islam; while the Animal Task Force/Ministry of Agriculture considered it to be a case of animal cruelty. ${ }^{3}$ This then, overrides the interpretive tyranny, which so often assumes that the author is the key source of the meanings in a text or image. Meaning therefore, according to Barthes, lies in the interpretation of the receivers (Internet users), which is far more important than what the author intended to convey. This insight serves to justify the use of images by young people to circumvent surveillance and censorship by the government. It teaches us that it is the readers' right to attribute a meaning to an image of their own. Consequently, political change does not necessarily occur because of the use of technology, but because of how the young people appropriate the various open source technologies available to them to use, interpret and derive meaning from the images and videos they find on social media such as Facebook, Twitter, and YouTube. While technology could partially reveal why certain social and political changes occurred, technology should not be looked at in isolation from other social processes which are also bearer of social change because by itself technology can neither bring about social nor political change (Prodnik 2012). Users can upload images on social media, but the images only have the power to create political change when users interpret them accordingly as highlighted in the video, Occupy Parliament Protests with Boniface Mwangi and James Smart. ${ }^{4}$

In our contemporary multi-modal age, a single medium can no longer be the message. Therefore, a sign (For instance the word $\mathrm{MPig}^{5}$ ), which is a political term in the Kenyan context, is involved in a three-part relationship. A sign establishes a relationship between a signifier (a picture of a pig outside the Kenya parliament) and signified (greed), which is often a sound image and a concept (Allen 2003). While Saussure omitted physical objects or images and considered language as a first order system involving a signifier and a signified, combined to a sign, Barthes's myth looks at how signs function within a cultural context and turns first-order meaning (denotation) into second order meaning (connotation) by taking the already existent sign and turning it into a signifier for a new signified or concept, thereby using the first order meaning (greed) to convey second order meaning (Members of parliament) (ibid.). Therefore, often a sign will elicit varied meanings based on the cultural contexts of the users. It can thus be argued that videos (audio-visual) and photographs (visual) posted online by young people in Kenya will elicit different interpretations depending on how the signifiers and the signifieds are positioned in processes of interpretation. Consequently, images posted by the youth in Kenya, are interpreted differently by users from different culture zones either within the national boundaries or transnational such as the Middle East, Ameri-

\footnotetext{
${ }^{3}$ Accessed on January 14, 2014. http://www.youtube.com/watch?v=tvcSsh-NHuQ. Running time: (03:47); key audiovisual narratives: $01: 00$ to $01: 10 ; 01: 40$ to $01: 58 ; 02: 55$ to $03: 40$.

${ }^{4}$ Accessed on January 14, 2014. http://www.standardmedia.co.ke/ktn/video/watch/2000068866/-occupyparliament-protests. Running time: (30:43); key audiovisual narratives: 03:10 to 03:55; 04:30 to 05:10; $10: 20$ to 11:10.

${ }^{5}$ The term MPig emerged from the OPM protests which compared Members of Parliament to pigs. It was later adopted by Kenyans, particularly on social media, when referring to their MPs in a derogatory manner.
} 
ca or Western Europe as highlighted in the video, Pig Protest: Reactions over occupy parliament. ${ }^{6}$

After the 2013 elections in Kenya, numerous political images posted by young people online, such as images of Kenyans celebrating the election of Uhuru Kenyatta as president although he is facing charges of crimes against humanity at the International Criminal Court, elicited different reactions within Africa and from different parts of the world. Diverse conclusions were drawn from the images. Some argued that it represented a country deeply polarised along ethnic lines, where the dominant tribes continue to dictate who wins the elections (Oyunga 2013; Wamwere/The Star 2013; Wrong/International Herald Tribune 2013); while it signified to others self-assertion by citizens of an emerging democracy about the civic rights to elect a president of their choice (Holligan/BBC 2013; Kimani/CNN 2013; Kimenyi 2013b; Perry/Time 2013; Warungu/BBC 2013). Still others argued that these pictures were evidence of the Kenyans' readiness to forgetting and forgiveness, as emulated by William Ruto joining forces with foe-turned-friend and fellow ICC inductee, Uhuru Kenyatta to secure a win (Kimenyi 2013a; Wambugu/The Star 2013). It was assumed that these pictures were meant as a message to the International Criminal Court (ICC) that Kenya was on a path towards reconciliation. Therefore, from the example above, the interpretation of images goes beyond first-order meanings. The example shows that an image can be interpreted in multiple ways, depending on the Internet user's beliefs, opinions and preferences.

\section{Social Media and Connectivity: Taking down the Boundaries}

As the Internet and computer networks expand and integrate with everyday life, questions as to who their users are have shifted to questions concerning the purpose for which the Internet is being used (Haythornthwaite 2005). A central issue has been the concept of connectivity, the question of how the internet moves from a system primarily oriented to information provision into a system oriented to communication and community building (Fuchs et al. 2012). The Internet is a technical means of connecting people. It has been credited for being a global medium which has increased the connectivity of internet users across the globe, thereby permitting the local to become global, and vice versa (Haythornthwaite 2005; Warf and Grimes 1997). Its interlinking potential has often described as the most defining characteristic of the medium, since it has been inscribed into how the technology of the Internet was developed (Moussa 2013). However, while the Internet and social media opens up new lines of communication, it also structures who talks to whom (Haythornthwaite 2005). For example, varied protest groups all over the world (Trayvon Martin Protests 2013; Occupy Parliament Kenya 2013; Occupy Parliament Reloaded 2013; Mexican Youth Protests 2012; Occupy Wall Street 2011; Walk to Work Protests Uganda 2011; London Riots 2011; Arab Spring 2010; Unga Revolution Kenya 2008) have utilised the internet which is a global platform to mobilise themselves on national issues. One of the main features of the Internet is that it has created virtual communities. However, when it comes to the use of online images, the diverse virtual communities tend to interpret the same images differently, depending on whatever unifies them as a group. New media platforms are therefore socio-technical and cultural-ideological constructs built to create and mediate connectivity, which is a co-production of humans and machines, with a more prominent but hidden role for technology (Dijck 2013 144). What is casually called community formation is often a product not exclusively of human connectivity but also of technical connectivity (ibid., 147). Therefore, it is necessary to deliberate on how social media operates in the current digital culture defined by connectivity.

Furthermore, there is need to look beyond individual platforms, too, and to approach them as dynamic structures evolving in close connection to each other and to culture at large (Dijck 2013, 150). Consequently, when the youth in Kenya post information on twitter and Facebook about political events in the country, such as the Occupy Parliament movement (OPM) of May 14, 2013, which drew inspiration from the Occupy Wall Street (OWS) protest of September, 2011, New York, the images elicit multiple interpretations. When civil society

\footnotetext{
${ }^{6}$ Accessed on January 14, 2014. http://www.youtube.com/watch?v=tvcSsh-NHuQ. Running time: (03:47); key
} audiovisual narratives: $01: 00$ to $01: 10 ; 01: 40$ to $01: 58 ; 02: 55$ to $03: 40$. 
activists used live pigs in front of the Kenyan parliament while demonstrating against MPs hiking their salaries, the information from one cultural zone was interpreted differently by the Internet users from another cultural zone in the world. A look at the Twitter handle \#OccupyParliament, and the Facebook page, Kenyans Occupy Parliament Now, reveals a myriad of interpretations to the images (Facebook 2013a; Twitter 2013; Nyumu/News24Kenya 2013; Moore/Aljazeera 2013) As previously mentioned, the concept of Barthes's essay Camera Lucida and the obtuse meaning (third meaning), can be used to apply to this case of visual communication. The third (obtuse) meaning is the excessive, exorbitant meaning that extends beyond culture, knowledge and information, and one which consciously employs two other levels of meanings to create the narrative (Barthes 1970, 44; Barthes 1981; Lin 2007; Attridge 1997). It can therefore be argued that, on $14^{\text {th }}$ May, 2013, while the civil society activists poured animal blood outside parliament and used a live pig and piglets as a symbol of protests (against the greed by the MPs who were demanding to hike their salaries, yet a significant number of Kenyans live below the poverty line), their actions were interpreted in different ways. Members of the Muslim community protested against a pig being used, while other Internet users interpreted it as a sign of animal cruelty. ${ }^{7}$ Consequently, the second protest that took place on $11^{\text {th }}$ June 2013, dubbed Occupy Parliament Reloaded, used an effigy of a pig instead of live pigs, as they poured animal blood outside parliament buildings (Facebook 2013b; Moore/Aljazeera 2013; Mutambo/Africa Review 2013).

While from a technological perspective, connectivity can be defined as the unbiased transport of packets between two endpoints; technology shapes sociality as much as sociality shapes technology (Dijck 2013, 146). This is also a process in which humans and machines have their own distinctive but mutually shaping roles in redefining political discourses among the youth in Kenya. Networks and networking has always been central to social movement, structure and collective action (Moussa 2011). However, the users' agency is a driving force of each platform's performative infrastructure. For example, people express their tastes and preferences, while algorithms translate them into relational databases that, in turn, inform user behaviour (Beer 2009). Consequently, algorithms have been responsible for taking down the boundaries between private and public spheres online. Often, technology, through the use of algorithms, has been used to give Internet users of communities' suggestions, which they might find interesting or appealing depending on their online behaviour. Consequently, Web 2.0 platforms are active mediators between users, technologies and content (Dijck 2013, 142), and once networks are established, there are several ways of recruiting people to join a cause (Thackeray 2010). This can be through the use of algorithms to identify individuals with similar preferences and lifestyles. According to Dijck (2013), when Google took over YouTube in 2006, it never aimed at making a profit on the exchange of home videos. Instead, it was mainly interested in YouTube's data revealing patterns concerning user's interests and patterns of behaviour, in order to connect these patterns to other Google databases and sell relevant information and space to advertisers. In addition, sites such as Facebook, direct users towards sharing their posts with as many people as possible and actively encourage them to join groups that appear to be of interest to an individual, based on an automatic detection of shared taste or contacts (ibid., 147).

Thus, in global information societies, social relations and community formation are reduced to communications. In such cases, power is not just in the flows, but also in the emergent non-linear socio-technical systems that channel, block or connect these flows (Lash 2007). The connotation of 'community' has been transferred from a context of human connectivity to a context of engineered connectivity, while keeping its human-centric meaning, even though technology is now the determining factor in defining sociality (Dijck 2013, 1478). Therefore, while the internet can be seen as providing opportunities for constructing dynamic structures in public spaces online, it can also be deemed problematic and challenging in many respects (Cammaerts 2009,558). This concern is borne out of the knowledge that while millions of young people in Kenya continue to join the social networks in large num-

7 Accessed on January 14, 2014. http://www.standardmedia.co.ke/ktn/video/watch/2000068866/-occupyparliament-protests. Running time: (30:43); key audiovisual narratives: 03:10 to 03:55; 08:10 to 08:28. 
bers, many are unaware that the images they consider to be personal and private, in an era of global communications become information available to public consumption and interpretation.

\section{Images as Representations of Online Myths and Narratives}

Online visual representations of political events are major forms of re-writing the narratives of political experiences by the youth in Kenya. When the youth interact with images, the image is positioned as a way the youth have experienced the world. They act as tools for the youth to grab hold of it, however imperfectly (Hunt and Schwartz 2010, 268). Hence, most websites and online content are necessarily visual in nature (Nahai 2012).

Often the youth interact with globally media-generated images, using them to construct meaning about political issues (Gamson, Croteau and Hoynes 1992). Images in general have a deeply ambivalent relationship to time. A single still image appears to freeze, capture, and memorialise political events, and in doing so works against the flow of duration (Hunt and Schwartz 2010, 259). Online images, by contrast, are framed on the basis of the cultural backgrounds and political experiences of the users. However, as noted by Barthes, the framing of the image by the user does not guarantee the meaning derived from it by other Internet users interacting with the image. Therefore, meanings assigned to online images are characterised by political discourse contexts among Internet users with regard to the diversities among them. For instance, when the city hall workers in Nairobi County went on strike in September 2013, demanding the implementation of a collective bargaining agreement (CBA), the women county representative and the governor of Nairobi County got into an alteration. Social media was a float with images of the male governor slapping the county's female representative. The image went viral, eliciting many varied responses. It was circulated among the youth on social media in Kenya and framed their views and opinions about the political leaders of Kenya. However, of particular importance were the varied conflicting arguments that arose on social media to justify or condemn the action. The discussions on online media were ethnically and politically motivated.

Hence, the outcomes of user interactions with visual technologies are not predictable. They depend either on their affordances or the intentions of its creators and users (Robin 2011). Questions were then asked on online platforms about his personal history and whether the politician had a violent record or not. A process such as this has been referred to as "filling in the blanks" during the process of interacting and interpreting political images. Therefore, images do not only provide a rich field for tapping into various kinds of non-verbal experience, they also require attention to the history of unconscious motivation and the experience of the other senses (Hunt and Schwartz 2010, 269).

It can also be argued that images are inherently multivalent. They all have some kind of relationship to the world they capture but only because it makes sense for us to see them in such ways (Hunt and Schwartz 2010, 268). The history of "filling in the blanks" is, in and of itself, an important way of examining the relation between images and their historical record (Hunt and Schwartz, 2010, 261). The same holds true of political narratives of young people in Kenya. During the 2007-08 political crisis in Kenya, when an image of Raila Odinga shaking hands with Mwai Kibaki, after signing the National Accord and Reconciliation Act, 2008, witnessed by Kofi Annan was uploaded on social media, it gave hope to millions of Kenyans. It was an image of hope for justice, peace, healing and reconciliation to the thousands of Kenyans who had been killed, displaced, and/or were on the streets and villages fighting for what they considered to be a rigged election.

Images are also resolutely historical since they incorporate a long history of techniques, preferences for subjects, and expectations about viewers (Hunt and Schwartz 2010, 259). The outcomes of youth engagement with technology are complex and unpredictable (Robin 2011). Therefore, when this image of reconciliation was circulated, it testified that violence has come to an end and the country could therefore embark on restoring peace and justice to a nation that had been often associated with an image of a beacon of stability and democracy in Africa. However, no image stands alone, and some images are best grasped when 
bundled in large groups of like images (Hunt and Schwartz 2010). A "visual narrative" is a story as enacted or told through a set of images. Rearranging these images leads to a shift and sometimes a dramatic change in the narrative. Political images of Kenya's history present an interesting panoramic view of political events and transformations that the nation has experienced.

\section{Visual Hegemonies and Biases/Inequities in Virtual Flows}

Cybercultures are prone to power struggles, inequalities, subversions and appropriations, as any other cultures (Near 2010,4). One should be neither optimistic nor pessimistic about the transformation of power structures on the Internet (Fuchs et al. 2012). While the internet is often credited for opening up public spaces for political expressions, it has also been blamed for promoting digital divides and perpetuating hegemonies, often the western culture dominating over other cultures. Consequently, social media becomes a platform for North-South contestations of visual cultures and hegemonies. This is taking into account that images that are posted on private online spaces and that profiles can also be used as public images to promote political stereotypes about others in order to create political subjectivities in a global world.

Due to its socio-technical nature, any attempts to make the Internet universal are also attempts to continue propagating technological hegemonies. The conceptualisation of hegemony is rooted in the Marxist view of the economic foundations of a society as the most important determinants of culture, values, and ideology (Altheide 1984). When we talk about universality and hegemony, we refer to the use of dominant images leading to the alienation of certain cultures (subordinated images) in order to embrace the global cultures (dominant images) or universality in political approaches and models. Therefore, while social media use has often been described as being democratic and free from censorship, this is not always the case, as can be explained by the panopticon model of surveillance (Lyon 2006; Foucault 1977), which is based on the assumption that users are constantly being watched, although they cannot see the ones who are watching them. The "supervisors", are the social networks and/or national governments, while the "prisoners" are Internet users, whereby all their profiles connect and converge to form one network under the surveillance of the social networks, criminal intelligent agencies and national governments.

It has often been argued that new ICTs offer platforms through which citizens become recipients of information and creators and disseminators of information (Martin and Olorunnisola 2013). Web 2.0 has brought with it the possibility of user-generated contents. However, user demographics reveal that while a majority of social media users is from the Northern hemisphere, the use of the Internet in the Southern Hemisphere is still limited because of economic and political factors. Consequently, Internet users in Kenya often appropriate online images from the North, while describing or discussing the politics of emerging democracies. A good case is the Occupy Kenya Parliament (OPM) Movement, which was borrowed from the Occupy Wall Street (OWS) Movement of New York. Hence, visual hegemonies reflect how political images from the North dominate over political images emanating from the South. As a result, the images are often pervasive insofar as they collectively constitute a visual hegemony, which is a codification of representations so ubiquitous that those seeking to craft a representation (of the politics of emerging democracies) need to deploy it to be easily understood (Ciarlo 2011). Hegemony is the democratic polity constituted through the principle of exclusion, thus, the transnational includes the North, but it excludes the South, while nationally it involves political actors excluding the youth from mainstream political discourses. These therefore return to haunt the polities predicted in their absence (Butler 2000, 11). Thus, in the analysis of how national cultures relate to global forces, five dimensions/scapes of the global cultural flows need to be studied: ethnoscapes, mediascapes, technoscapes, financescapes, and ideoscapes (Appadurai 2000). With the proliferation of new media technologies, the diverse global flows have converged in new media platforms and have become transnational, beyond the control of many national governments. As a result, the five "scapes" are clear manifestations of the creation of online visual hegemonies, such as eth- 
nocentrism, media imperialism, digital artefacts, global capital and political ideologies with particular emphasis on how they are shaped and influenced by local and global political forces.

While the Internet serves both hegemonic and counterhegemonic purposes (Warf and Grimes 1997), contrary to commonly circulating myths, electronic spaces are being generated by ICTs, which are not free. Controls exist over domain names, bandwidth, access, and speed. Even surveillance technologies are put in place to monitor usage (Nayar 2010, 4). While users often feel that they are the producers and receivers of their content, often the social network sites are the beneficiaries. Facebook, for instance, is a capitalistic organisation whose main drive is profit accumulation (Netchitailova 2012). Consequently, in a bid to exert dominance, cyberspace is a contested terrain; a battleground of political discourses (Warf and Grimes 1997) and of inequities in information flows. In fact, one can argue that there is no one in cyberspace or cyber culture. In fact, cyber culture, like all social practices, is a consequence of political economy, the human world, information, global capital, capitalism, cables and wires, monitors, and SIM cards (Nayar 2010,4). All this involves an element of ownership and monetary returns. Hence, it perpetuates inequities, biased information flows between the North and the South, and hegemonies in online visual cultures. Consequently, global visual cultures are often dictated by the Western democracies. Visual hegemonies are historical and transitory (Ciarlo 2011), and Internet users adapt to the existing hegemonies with regard to their use of the political images and their interpretation. Often, the images selected, such as those about the South, which nevertheless emerge from the North. While inequities in virtual flows between the North and South serve to perpetuate visual hegemonies, the youth in Kenya are using new media platforms to correct the media hegemony by rewriting their own stories on a platform that is not just national, but transnational.

\section{Surveillance and Censorship of Online Images}

Surveillance is not a new concept. It has always existed. What has changed or improved are the means of surveillance. Surveillance, which for most of human history was a matter of face-to-face, augmented with forms of recording, is now characterised by high-technology applications (Lyon 2007) The advancement in new media technologies has heightened the panopticon concept of surveillance as being invisible and not easy to trace (Mathiesen 2012). While the panopticon concept was centralised as opposed to Internet surveillance, which is mainly decentralised, the concept of panopticon has heavily influenced discussions about Internet surveillance (Fuchs et al. 2012). This is based on the assumption that through Internet surveillance, individuals' lives are much more visible, and anything posted online can be retrieved, leading to disastrous consequences (Netchitailova 2012). During the 2013 elections in Kenya, the National Commission for Integration and Cohesion ( $\mathrm{NCIC}$ ) monitored all political discussions and exchanges on social media in order to arrest anyone who engaged in hate speech during the political campaigns.

While surveillance in general is often used with negative and critical connotations, participatory surveillance is a more positive notion focusing on potentially empowering aspects of surveillance (Albrechtslunnd 2012; Prodnik 2012). Social networks, such as Facebook, often ask for one's real name when signing up (Netchitailova 2012). While their "real name"-policy has been criticised for putting users at risk, it has also been credited for hindering and/or limiting cybercrimes. However, people have also criticised that internet users' data have become available on public networks, such as Facebook, and that apps are being developed which use such data in order to track and to monitor users' online behaviour. Technologies such as "cookies, data mining, collaborative filtering, ambient intelligence, clickstream analysis, spyware, web crawlers and log file analysis allow an extension and intensification" of surveillance of internet users (Fuchs et al. 2012, 9-10). For example, Facebook had an app "Find Friends Nearby"; which has meanwhile been removed due to privacy concerns. However, the Circle is another type of invasive location based on social networking techniques making use of the geographical location of users, using data drawn from Facebook. It also reveals users' activities, such as profiles views, thereby publicly displaying users' online be- 
haviours and preferences. This network has an interface with the potential of being used to mobilise political activists. How users in Kenya embrace and interpret its relevance to their own lives remains to be seen. In sum, with reference to Roland Barthes's Death of the Author, the social utility and relevance of the Circle social networking site will have to be determined by how the users in Kenya (readers) choose to "read" the messages (interpret political images), and not necessarily what the developers (authors) intended.

While the increasing digitalisation may coincide with increasingly invasive surveillance techniques and continuous commodifications of social life in Kenya (sometimes seen as a necessary precondition for making such detailed and continuous surveillance possible) neither of these processes happened because of technology and their supposedly neutral development in the last decades (Prodnik 2012, 92). Surveillance has been a practice often carried out by governments and other institutions such as schools and employers. What has changed with digitalisation is the scale of surveillance and the means of surveillance. Consequently, privacy has become an antagonistic value in the digital age. This is because while the users in Kenya, for instance, expect that the social networks will protect their private data, the advertisers expect the social networking sites to provide them with Internet user behaviours and preferences (Netchitailova 2012; Fuchs 2011). Social surveillance should therefore not be seen as some inherent quality brought upon the multitude by digital technologies, but as something that is embedded in them and (ab)used because of wider political, economic, and social pressures, influences and expectations (Prodnik 2012, 92).

It has been argued that the Internet allows unfiltered, non-hierarchical flows of information, in a raucous, highly democratic world with no gatekeepers and numerous countercultures of hackers (Mungo and Clough 1992; Rheingold 1993; quoted in Warf and Grimes 1997). Nevertheless, this is not often the case, as in Kenya, when the government passed laws intended to prosecute individuals engaging in online speeches of "hatred". In the campaign to the 2013 elections, bloggers were arrested for expressing sentiments on their blogs that were evaluated as "hate speeches". Therefore, the ability of governments to censor these modes of communication has and will continue to be an area of concern in the emerging role of new ICTs as platforms of preference by citizens engaged in political activism and social movements (Martin and Olorunnisola 2013; Netchitailova 2012). This is because Internet surveillance has serious implications for political regulation, state power, and civil society (Fuchs et al. 2012) in addition to youth activism and social movements. For instance, when the Walk to Work Protests started in 2011 in Uganda, the Communications Commission of Uganda ordered all Internet service providers to block Facebook and Twitter, blaming them for fuelling the flames. However, in other cases, filters can be employed by the social networking sites, on a national platform. Filtering on national platforms is often done because norms with regard to what counts as appropriate or inappropriate content are very much culturally defined which is why most platforms deploy national filters (Dijck 2013, 148). Protocols, both technical and regulatory, are thus put in place to keep platforms clean from polluting traffic. For instance, Facebook insists on a "real name" policy, even when human rights activists, for example, have warned Facebook that this policy may endanger people's lives in countries on which police or militias monitor citizens very closely (Dijck 2013, 148). YouTube not only deploys algorithmic spiders to detect forbidden content but also keeps up a system of human vigilance to filter out inappropriate messages (Dijck 2013, 148).

These filters can also be imposed on platforms by national governments, as illustrated in China and Iran, forcing a platform owner either to censor a site's content or to modulate its protocols (Dijck 2013, 148). However, while the Kenyan government has not engaged in technical filtering, it has engaged in intensive surveillance, especially during the electioneering period, in attempts to monitor online "hate speech". Kenya's historical experiences have created concerns about "hate speech and violence, leading to efforts aimed at censoring inappropriate messages that are intended to harm internet users or compromise the security of the nation. In the aftermath of the 2007-08 political crisis in Kenya, the government announced its intention to prosecute individuals who had posted inflammatory texts and images online. The citizens were also required to register all mobile phones and modems used for Internet access with the Communications Commission of Kenya (CCK) or face disconnec- 
tion. As a result, in the run up to the 2013 elections, the youth shied away from using mobile phone SMS for hate speech, with the knowledge that the government had access to their mobile phone users' data and was doing mass dataveillance to track hate speech offenders and prosecute them. They then shifted to using social networking sites, often using pseudo names or using public computers in libraries and cybercafés, to avoid being easily identified. However, the government, in conjunction with the National Commission for integration and cohesion (NCIC) issued threats to arrest those who posted images or videos that were inciting or could be considered as hate speech. Surveillance is often carried out to monitor what the youth post online and whether it has ramifications for the safety of other Internet users and the security of a nation. The nature and quality of content (whether communicative traffic or creative content) is primarily controlled in order to guarantee "good connectivity" to its users (Dijck 2013, 148). If a network gets clogged with inappropriate content, then it loses relevance for the users. Hence, technology is no autonomous actor (Prodnik 2012), but a mediator between the youth and other social and political actors engaged in surveillance and technical filtering.

However, technical filtering and surveillance is also gaining importance: It is becoming more invasive in postmodern capitalist societies (Prodnik 2012). There is an enormous amount of undiscovered surveillance practices on the Internet (Mathiesen 2012), and its potential for surveillance is spreading throughout society and people's lives with the help of the Internet's omnipresent attributes (Prodnik 2012). Surveillance is also considered to be a form of critical, negative and oppressive domination because political surveillance on the internet acts as a panopticon system that silences people in a suave and silent way (Mathiesen 2012), with the internet being manipulated by dominant forces (government, corporate and lobby groups) in the society to control the minds of the weaker groups (minority groups, urban poor, women and youth) in society. The idealism that has celebrated the web as a harbinger of freedom and democratisation platform has been challenged by the power struggles - as well as relations of the material world, characteristic of the online public spheres today (Prodnik 2012). Consequently, the application of technology and surveillance is connected to "complex material contradictions and power-relations" (Prodnik 2012, 93) between the youth and dominant political actors in Kenya who seek to implement surveillance based on a panopticon model of surveillance that subjects the users of social media to a position of constant visibility.

\section{Conclusion}

Social media has provided opportunities for the youth in Kenya to successfully participate in social and political change, by giving them a voice and a chance to be involved in civic affairs (Thackeray 2010). Often, even in cases where the government attempts to monitor youth political discourses, the youth have resorted to using images, which, while they do not automatically convey what they mean, they still carry subtle meanings that the youth can identify. For instance, today on social media, an image of a human being with a head of a pig symbolises a member of parliament. However, if digital communication technologies are to develop more fully into dense networks that enable grassroots challenges, their regulation needs to be guided by their most innovative users (Bennett 2004), that is, the youth in Kenya, and not the government. Furthermore, there is also need to pay more attention to bottom-up political appropriation of ICTs in Kenya (Moussa 2013).

As discussed above, outcomes of the use of any particular ICT by the youth in Kenya are not foretold by its properties since affordances and constraints build into technology may limit or enable a range of actions. As such, outcomes of technology are not fully predictable based on either its affordances or the intentions of its creators and users (Robbin 2011). Hence, the political impact of the Internet cannot be attributed to intrinsic qualities of the technology alone; neither can it be reduced to one specific platform (Moussa 2013). The debate concerning the potential of the Internet for political change is about the technology as a medium. The impact of the Internet can hardly be disassociated from other communication tools and networks, including the unmediated ones (ibid.). Therefore, positing technological 
changes (digital images) as bearers of social change, without looking at complex social relations that influence the development of technology (digital political images) is doomed to failure (Prodnik 2012, 92). The question of how young people in Kenya interact with the Internet is determined by a variety of factors. They range from infrastructural concerns and financial requirements to concerns about exclusion or inclusion of young people in politics and cultural and political stereotypes, determining the use of social media for emancipating young people.

\section{References}

Albrechtslund, Anders. 2012. Socialising in the City: Location Sharing and Online Social Networking. In Internet and Surveillance: The Challenges of Web 2.0 and Social Media, by Christian Fuchs et al., 187-197. New York: Routledge.

Allen, Graham. 2003. Roland Barthes. London: Routledge.

Altheide, David, L. 1984. Media Hegemony: A Failure of Perspective. The Public Opinion Quarterly. 48 (2): 476-490.

Appadurai, Arjun. 2000. Modernity at Large: Cultural Dimensions of Globalisation. Minneapolis: University of Minnesota Press.

Attridge, Derek. 1997. Roland Barthes's Obtuse, Sharp Meaning, and the Responsibilities of Commentary. In Writing the Image after Roland Barthes, edited by Jean-Michel Rabate 77-89. Pennsylvania: University of Pennsylvania Press.

Auskalniene, Lina. 2012. Assessing Participation Online: Youth and Their Involvement in Social Media. Informacijos Mokslai 59: 105-116.

Barthes, Roland. 1970. The Third Meaning: Research Notes on Several Eisenstein Stills. The Responsibility of Forms: Critical Essays on Music, Art and Representation. Trans. Richard Howard, 44-68. Berkley: University of California Press.

Barthes, Roland. 1981. Camera Lucida: Reflections on Photography. Trans. Richard Howard. New York: Hill and Wang.

Barthes, Roland. 1989. The Rustle of Language, trans. Richard Howard. Berkley: University of California Press.

Holligan, Anne. 2013. Did the ICC Help Uhuru Kenyatta Win Kenyan Election? BBC Africa News. March 11. Accessed $27^{\text {th }}$ September, 2013. http://www.bbc.co.uk/news/world-africa-21739347.

Beer, David. 2009. Power through the Algorithm? Participatory Web Cultures and the Technological Unconscious. New Media \& Society 11: 985-1002.

Bennett, W Lance. 2004. Global Media and Politics: Transnational Communication Regimes and Civic Cultures. Annual Review of Political Science 7: 125-148.

Bimber, Bruce, Andrew J. Flanigan, and Cynthia Stohl. 2005. Reconceptualising Collective Action in the New Media Environment. Communication Theory 12 (5): 365-388.

Butler, Judith. 2000. Restaging the Universal: Hegemony and the Limits of Formalism. In Contingency, Hegemony, Universality: Contemporary Dialogues on the Left, edited by Judith Butler, Ernesto Laclau, and Slavoj Zizek, 11-43. New York: Verso.

Cammaerts, Bart. 2009. Radical Pluralism and Free Speech in Online Public Spaces: The Case of North Belgian Extreme Right Discourses. International Journal of Cultural Studies 12 (6): 555-575.

Castells, Manuel. 1997. The Power of Identity. Oxford, UK: Blackwell.

Ciarlo, David. 2011. Advertising Empire: Race and Visual Culture in Imperial Germany. USA: President and Fellows of Harvard College.

Diamond, Larry. 2010. Liberation Technology. Journal of Democracy 21 (3): 69-83.

Dijck, Jose Van. 2013. Facebook and the Engineering of Connectivity: A Multi-Layered Approach to Social Media Platforms. Convergence: The International Journal of Research into New Media Technologies 19: 141-155.

Douai, Aziz and Anthony Olorunnisola. 2013. New Media and the Question of African Democracy. In New Media Influence on Social and Political Change in Africa, edited by Anthony Olorunnisola and Aziz Douai, 1-14. Hershey PA: IGI-Global.

Facebook. 2013a. Kenyans Occupy Parliament Now. Accessed September 30, 2013. https://www.facebook.com/pages/Kenyans-Occupy-Parliament-Now/279432342194380.

Facebook. 2013b. Occupy Parliament Reloaded. Accessed September 30, 2013. https://www.facebook.com/events/410339199063590/.

Foucault, Michel. 1977. Discipline and Punish: The Birth of the Prison. New York: Pantheon Books. 
Fuchs Christian. 2012. Towards Marxian Internet Studies. tripleC - Cognition, Communication, Cooperation: Open Access Journal for a Global Sustainable Information Society 10 (2) 392-412. Accessed June 6 2013. http://www.triple-c.at/index.php/tripleC/article/view/277

Fuchs, Christian. 2011. Foundations of Critical Media and Information Studies. London: Routledge.

Gamson, A. William, David Croteau, William Hoynes, and Theodore Sasson. 1992. Media Images and the Social Construction of Reality. Annual Review of Sociology 18: 373-393.

Goldstein, Joshua and Juliana Rotich. 2010. Digitally Networked Technology in Kenya's 2007-08 PostElection Crisis. In SMS Uprising: Mobile Phone Activism in Africa, edited by Sokari Ekine, 115136. Oxford, UK: Pambazuka Press.

Haythornthwaite, Caroline. 2005. Social Networks and Internet Connectivity Effects. Information, Communication and Society 8 (2): 125-147.

Hunt Lynn and Vanessa R. Schwartz. 2010. Capturing the Moment: Images and Eye Witnessing in History. Journal of Visual Culture 9: 259-271.

Kimani, Faith. 2013. President-Elect Uhuru Kenyatta of Kenya a Man of Complexities. CNN, March 30. Accessed September 27, 2013. http://edition.cnn.com/2013/03/10/world/africa/uhuru-kenyattaprofile/index.html

Kimenyi, Mwangi S. 2013a. Kenya: A Country Redeemed after a Peaceful Election. Accessed September 27, 2013. http://www.brookings.edu/blogs/up-front/posts/2013/04/02-kenya-peacefulelections-kimenyi

Kimenyi, Mwangi S. 2013b. Kenya's Uhuru Kenyatta Deserves Support of the International Community. Accessed September 27, 2013. http://www.brookings.edu/blogs/up-front/posts/2013/03/11kenya-elections-kimenyi

Oyunga, Stan. 2013 Elections: Tyranny of Numbers - Fact or Myth? Kenya Election Database. Your Guide to Elections in Kenya. Accessed September 27, 2013. http://kenyaelectiondatabase.co.ke/?p=1202

Lash, Scott. 2007. Power after Hegemony: Cultural Studies in Mutation? Theory, Culture and Society. 24 (55): 55-87.

Lin, Ke-Ming. 2007. The Lacanian Spectator: Lacanian Psychoanalysis and the Cinema. UMI Microform. 3275744. Michigan: ProQuest Information and Learning Company.

Ludes, Peter (Ed.). 2005. Visual Hegemonies: An Outline =The World Language of Key Visuals. Computer Sciences, Humanities, Social Sciences, vol. 1, edited by Peter Ludes and Otthein Herzog. Berlin: LIT.

Lyon, David. 2006. Theorizing Surveillance: The Panopticon and Beyond. Cullompton, UK: Willan Publishing.

Lyon, David. 2007. Surveillance Studies. An Overview. Cambridge, UK: Polity Press.

Martin, L. Brandie and Anthony A Olorunnisola. 2013. Use of New ICTs as "Liberation" or "Repression" Technologies in Social Movements. In New Media Influence on Social and Political Change in Africa, edited by Anthony Olorunnisola and Aziz Douai, 257-272. Hershey PA: IGI-Global.

Mathiesen, Thomas. 2012. Preface. In Internet and Surveillance: The Challenges of Web 2.0 and Social Media, edited by Christian Fuchs et al. xv-xx. New York: Routledge.

Moore, Phil. 2013. In Pictures: 'Occupy Kenya' Aljazeera. June 15. Accessed October 4, 2013. http://www.aljazeera.com/indepth/inpictures/2013/06/2013612105845379954.html

Moussa, M. Ben. 2013. A Grassroots Approach to the Democratic Role of the Internet in Developing Countries: The Case of Morocco. In New Media Influence on Social and Political Change in Africa, edited by Anthony Olorunnisola and Aziz Douai, 218-240. Hershey PA: IGI-Global.

Moussa, M. Ben. 2011. The Use of Internet by Islamic Social Movements in Collective Action: The Case of Justice and Charity. Westminster Papers in Communication and Culture 8 (2): 63-92.

Mungo, Paul and Bryan Clough. 1992. Approaching Zero: The Extraordinary Underworld of Hackers, Phreakers, Virus Writers, and Key Board Criminals. New York: Random House.

Mutambo, Aggrey. 2013. Kenyans Stage another Protest against MPs' Greed. Africa Review, June 11. Accessed, October 4, 2013. http://www.africareview.com/News/Kenyans-stage-another-protestagainst-greedy-MPs/-/979180/1879086/-/1ap0z/-/index.html

Nahai, Nathalie. 2012. Webs of Influence: The Psychology of Online Persuasion. Edinburgh: Pearson Education Limited.

Nayar. K. Pramod. (Ed). 2010. Introduction. In The New Media and Cyberculture Anthology, edited by Pramod K Nayar, 1-7. Oxford: Wiley-Blackwell. 
Netchitailova, P. Ekaterina. 2012. Facebook as a Surveillance Tool: From the Perspective of the User. tripleC - Cognition, Communication, Co-operation: Open Access Journal for a Global Sustainable Information Society. 10 (2): 683-691. http://www.triple-c.at/index.php/tripleC/article/view/404 .

Nyumu, Pauline. 2013. Occupy Parliament Event Causes a Stir on Twitter. News24Kenya. Accessed September 30, 2013. http://www.news24.co.ke/Politics/OccupyParliament-event-causes-a-stir-onTwitter-20130514

Perry, Alex. 2013. Kenya's Election: What Uhuru Kenyatta's Victory Means for Africa. Time, March 09. Accessed September 27, 2013. http://world.time.com/2013/03/09/kenyas-election-what-uhurukenyattas-victory-means-for-africa/

Prodnik, Jernej. 2012. Toward a Critique of Surveillance in the Age of the Internet: A Reflection on the "Internet and Surveillance" tripleC - Cognition, Communication, Co-operation: Open Access Journal for a Global Sustainable Information Society 10 (1): 92-99. Accessed September 9, 2013. http://www.triplec.at/index.php/tripleC/article/view/342

Rheingold, Howard. 1993. The Virtual Community: Homesteading on the Electronic Frontier. Reading, MA: Addison-Wesley.

Robbin, Alice. 2011. Embracing Technology and the Challenges of Complexity. tripleC-Cognition, Communication, Co-operation: Open Access Journal for a Global Sustainable Information Society 9 (1): 11-27. Accessed September 9 2013. http://www.triple-.at/index.php/tripleC/article/view/245

Stanbridge, Alan. 2003. Continuum Encyclopedia of Popular Music of the World, Vol. 1: 111-117. London: Continuum.

Thackeray, Rosemary. 2010. Empowering Youth: Use of Technology in Advocacy to Affect Social Change. Journal of Computer-Mediated Communication 15: 575-591.

Twitter. 2013. \#OccupyParliament. Accessed September 30, 2013. https://twitter.com/search?q=\%23occupyParliament\&src=hash

Omanga, Duncan and Pamela Chepngetich-Omanga. 2013. Twitter and Africa's "War on Terror": News Framing and Convergence in Kenya's Operation Linda Nchi. In New Media Influence on Social and Political Change in Africa, edited by Anthony Olorunnisola and Aziz Douai, 241-256. Hershey PA: IGI-Global.

Wambugu, Ngunjiri. 2013. Now ICC Must Leave Uhuru Kenyatta, William Ruto Alone. The Star. April 1. Accessed September 29, 2013. http://www.the-star.co.ke/news/article-114870/now-icc-mustleave-uhuru-kenyatta-william-ruto-alone

Wamwere, Koigi. 2013. An Open Letter to President Uhuru Kenyatta and Deputy William Ruto. The Star April 6. Accessed September 29, 2013. http://www.the-star.co.ke/news/article-115537/openletter-president-uhuru-kenyatta-and-deputy-william-ruto

Warf, Barney and John Grimes. 1997. Cyberspace and Geographical Space. Geographical Review 87 (2): 259-274.

Warungu, Joseph. 2013. Kenya Passes Electoral Test - But what next? BBC News Africa, March 12. Accessed September 27, 2013. http://www.bbc.co.uk/news/world-africa-21745501

Wrong, Michela. 2013. The Most Useless Exercise in Kenya? International Herald Tribune. The Global edition of the New York Times. April 2, Accessed September 27, 2013.

http://latitude.blogs.nytimes.com/2013/04/02/kenyattas-victory-is-a-defeat-for-kenya-and-justice/

\section{About the Author}

Lusike Lynete Mukhongo

holds a PhD in Communication Studies from Moi University, Kenya. She lectures in the Department of Communication Studies, Moi University, and her research interests include social media and political engagement, Media, Human Rights and Governance; and Gender and Armed Conflicts. 